\title{
MAMPUKAH PROGRESSIVE MUSCLE RELAXATION (PMR) MENURUNKAN KADAR GULA DARAH?
}

\author{
Casman $^{1 *}$, Yulia Fauziyah ${ }^{2)}$, Ikha Fitriyana ${ }^{3)}$ \\ ${ }^{1)}$ Mahasiswa Program Studi Ilmu Keperawatan, STIKes Mahardika Cirebon, Dosen Akademi \\ Keperawatan RS Husada Jakarta \\ ${ }^{2)}$ Dosen Program Studi Ilmu Keperawatan, Universitas Jendral Soedirman Purwokerto \\ ${ }^{3)}$ Dosen Program Studi Ilmu Keperawatan, STIKes Mahardika Cirebon \\ *E-mail: nerscasman@gmail.com
}

\begin{abstract}
ABSTRAK
Penderita diabetes melitus meningkat setiap tahun, diabetes mellitus merupakan penyakit yang ditandai dengan hiperglikemia, yaitu tingginya kadar gula darah. Penderita diabetes melitus biasanya mengalami stress sepanjang hidupnya. Beberapa pencegahan dapat dilakukan pada penderita untuk mencegah komplikasi, salah satunya dengan progressive muscle relaxation yang mampu meningkatkan penyerapan insulin dan mengurangi stress. Tujuan penelitian ini adalah untuk menelaah efektifitas progressive muscle relaxation dalam menurunkan kadar gula darah puasa. Artikel ini merupakan bagian dari penelitian sebelumnya tentang perbedaan efektifitas progressive muscle relaxation dan latihan fisik dalam menurunkan kadar gula darah penderita diabetes mellitus tipe 2. Progressive muscle relaxation dilakukan selama 6 hari berturut-turut dengan dua sesi setiap hari, dimana satu sesi berdurasi 30 menit. Rata-rata responden berumur 50,37 tahun, dan hasilnya menunjukkan bahwa $\mathrm{p}=0,000(\mathrm{p}<0,05)$, yaitu terdapat penurunan kadar gula darah puasa pada kelompok intervensi dari 171,93 mg/dL (sebelum) menjadi 121,73 mg/dL (sesudah). Progressive muscle relaxation yang dilakukan dengan durasi 30 menit efektif menurunkan kadar gula darah puasa lansia dengan diabetes mellitus tipe 2.
\end{abstract}

Kata kunci : PMR, Kadar GDP, Diabetes Mellitus

\begin{abstract}
People with diabetes mellitus increase every year, diabetes mellitus is a disease characterized by hyperglycemia, which is high blood sugar levels. People with diabetes mellitus usually get the stress throughout their lives. Some prevention can be usefull on patients to prevent complications, progressive muscle relaxation can increase insulin absorption and reduce stress. The purpose of this research was to examine the effectiveness of progressive muscle relaxation in reducing fasting blood sugar levels. This article is part of a previous study, with tittle differences in the effectiveness of progressive muscle relaxation and physical exercise in reducing blood sugar levels in people with diabetes mellitus type 2. Progressive muscle relaxation is carried out for 6 consecutive days, two sessions per day, with duration 30 minutes per session. The results of this study was the average the respondents were 50.37 years old, and the results showed that $p=0,000$ ( $p<0.05)$, ie there was a decrease in fasting blood sugar levels in the intervention group from $171.93 \mathrm{mg} / \mathrm{dL}$ (pre) to $121,73 \mathrm{mg} / \mathrm{dL}$ (post). Progressive muscle relaxation with minumum duration 30 minutes is effective in reducing fasting blood sugar levels in elderly with diabetes mellitus type 2.
\end{abstract}

Keywords:PMR, FBS consentrate, Diabetes Mellitus

JKH/ Volume 3/ Nomor 1/Januari 2019 (ISSN: 2548-1843, EISSN: 2621-8704) 
PENDAHULUAN

World Health Organization

memperkirakan Penyakit Tidak

Menular (PTM) akan menyebabkan

sekitar $73 \%$ kematian dan $60 \%$

kesakitan di seluruh dunia pada tahun

2020 (Depkes RI, 2008).

Diabetes Melitus (DM) merupakan salah satu dari PTM yang dikenal dengan kencing manis atau penyakit gula. DM memang tidak dapat didefinisikan secara tepat, DM lebih merupakan kumpulan gejala yang timbul pada diri seseorang yang disebabkan oleh adanya peningkatan gula darah akibat kekurangan insulin baik absolut maupun relatif (Subekti, 2005).

Dilaporkan International Diabetes Federation pada tahun 2012 ada sebanyak 371 juta orang menderita diabetes di dunia, sejumlah 7,6 juta adalah penduduk Indonesia, sehinggan menempatkan Indonesia di posisi ke-7 dengan penderita diabetes terbanyak di dunia, di Asia Indonesia hanya kalah dari China dan India, sedangkan di Asia Tenggara, Indonesia adalah peringkat ke-1 2006). penderita diabetes terbanyak (Depkes RI, 2008).

Sachdev (2009) menjelaskan bahwa dari seluruh penderita DM, DM tipe 2 mencapai angka 90-95 \%, yang berarti menunjukkan bahwa penderita DM tipe 1 hanya berkisar 5-10\%. Fathoni dkk (2007) memperkirakan jumlah penderita DM, khususnya tipe 2 mencapai 300 juta orang pada tahun 2025.

Penderita DM lebih dari 8 tahun akan menyebabkan stress pada penderita, dimana dalam penelitiannya ada sebanyak $56,70 \%$ responden menderita DM lebih dari 8 tahun (Mashudi, 2012).

Stres akan mengaktifasi sekresi hormon adrenalin dan kortisol. Hormon adrenalin menyebabkan pelepasan glikogen di hati menjadi gula dan hormon kortisol bersifat antagonis terhadap pelepasan insulin. Sekresi hormon adrenalin dan hormon kortisol menyebabkan gula dalam pembuluh darah meningkat sehingga terjadilah hiperglikemia (Sudoyo dkk, 
Hiperglikemia berarti menunjukkan kadar gula dalam darah tinggi. Kadar gula dalam darah biasanya dijadikan patokan dalam menentukan apakah orang tersebut terkena diabetes atau tidak. Dimana nilai gula darah puasa biasanya lebih sering digunakan sebagai patokan. Gula darah puasa normal yaitu $80-125 \mathrm{mg} / \mathrm{dL}$ (Soewondo, 2005).

Kashaninia (2011) menjelaskan bahwa relaksasi efektif dalam meningkatkan penyerapan insulin dan meningkatkan sirkulasi yang mengarah ke penurunan kadar gula darah. Sustrani (2006) menjelaskan bahwa salah satu tipe relaksasi adalah progressive muscle relaxation (PMR). PMR merupakan cara yang efektif untuk relaksasi dan mengurangi kecemasan dan stress.

Tujuan dari artikel ini adalah untuk mengetahui efektifitas PMR dalam menurunkan kadar gula darah puasa (GDP) pada penderita DM tipe 2.

\section{METODE}

Artikel ini merupakan bagian dari penelitian yang dilakukan oleh Casman, Fauziyah, Fitriyana, dan
Triwibowo (2015) yang meneliti perbedaan efektifitas latihan fisik dan PMR dalam menurunkan kadar GDP penderita DM tipe 2 di Puskesmas wilayah Suranenggala Kab. Cirebon. Penelitian telah dilakukan 5-30 Mei 2013.

Artikel artikel ini hanya akan membahas efektifitas $\mathrm{PMr}$ dalam menurunkan kadar GDP pada kelompok intervensi yang diberi perlakuan PMR. PMR dilakukan kepada 15 responden dengan durasi sesi latihan 30 menit per sesi. PMR dilakukan selama 6 hari berturutturut. PMR dilakukan sebanyak 2 sesi setiap hari yaitu pada pagi dan sore hari.

\section{HASIL}

Hasil dari penelitian ini diperoleh rata-rata responden kelompok intervensi berumur 50,37 tahun dengan standar deviasi 7,039. Jenis kelamin laki-laki lebi banyak daripada perempuan yaitu 10 laki-laki $(66,67 \%)$ dan 5 perempuan $(33,33 \%)$. Rata-rata responden telah menderita DM Tipe 2 lebih dari 8 tahun $(53,33 \%)$. 
Seluruh responden menjunjukkan penurunan KGD setelah dilakukan PMR. Adapun perubahannya dapat dilihat dalam grafik 2 .

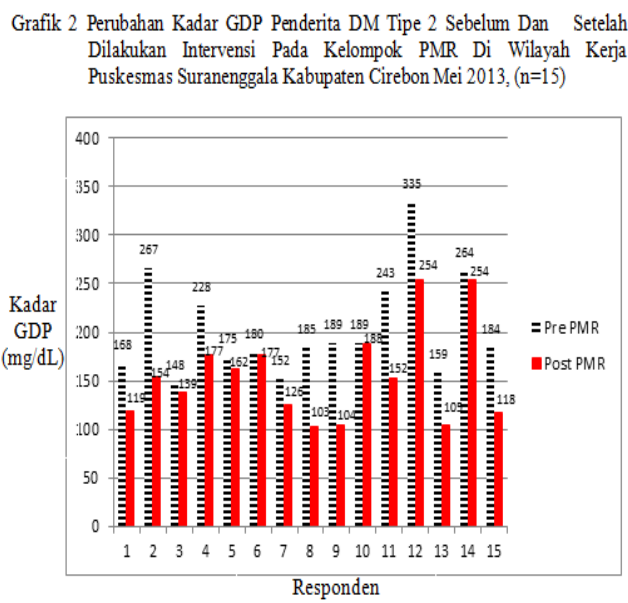

Sebelum intervensi PMR KGD terendah adalah $148 \mathrm{mg} / \mathrm{dL}$, sedangkan KGD tertinggi adalah 335 $\mathrm{mg} / \mathrm{dL}$, sedangkan setelah intervensi PMR KGD terendah $105 \mathrm{mg} / \mathrm{dL}$ dan tertinggi $254 \mathrm{mg} / \mathrm{dL}$.

Hasil analisis terhadap perbedaan KGD sebelum dan setelah intervensi PMR terlihat pada tabel 1 .

Tabel 1

Selisih KGD Pre Test dan Post Test Intervensi PMR

\begin{tabular}{ccccc}
\multicolumn{5}{c}{ Intervensi PMR } \\
\hline $\begin{array}{c}\text { Intervensi } \\
\text { PMR }\end{array}$ & Mean & SD & pValue & $\mathbf{9 5 \%}$ CI \\
\hline Sebelum & 171,93 & 45,14 & $0,000 *$ & \\
Sesudah & 121,73 & 25,93 & & $28,55-$ \\
& & & & 69,30 \\
Selisih & 50,20 & 38,52 & & \\
\hline \multicolumn{4}{l}{ Signifikan pada $\mathrm{p}<0,05$} \\
\end{tabular}

Hasil uji statistik didapatkan nilai $\mathrm{p}=0,000 \quad(\mathrm{p}<0,05), \quad$ sehingga dapat dikatakan bahwa PMR efektif menurunkan KGD pada penderita
DM tipe 2. Selisih antara rata-rata kadar GDP sebelum dan setelah intervensi pada kelompok PMR, dimana rata-rata kadar GDP pretest sebesar 204,04 mg/dL turun menjadi $155,47 \mathrm{mg} / \mathrm{dL}$ pada posttest.

\section{PEMBAHASAN}

Hasil penelitian menunjukkan PMR berpengaruh signifikan terhadap penurunan kadar GDP, dengan nilai $p=0,000$. Hasil penelitian ini sejalan dengan penelitian yang dilakukan Mashudi (2012), yang menyatakan bahwa latihan PMR pagi dan sore hari efektif menurunkan GDP dengan nilai $(p<0,05)$. Lebih rinci yaitu pagi hari pukul $06.00(\mathrm{p}=0,001)$ dan sore hari pukul $16.00(\mathrm{p}=0,003)$. PMR dalam penelitian Mashudi, dilakukan selama 3 hari berturut-turut dengan durasi 15 menit tiap sesi latihan.

Seluruh responden mengalami penurunan kadar GDP yang signifikan, dimana sebanyak 53,33\% responden telah menderita DM lebih dari 8 tahun, sehingga responden mengalami stress. Hal ini berdasarkan Sudoyo dkk. (2006) yang menyatakan bahwa Hubungan anatara fisik dan psikis telah menjadi perhatian para 
ahli dan para peneliti sejak dahulu. Keduanya saling terkait secara erat dan tidak didapat dipisahkan antara satu dengan lainnya. Pada kenyataannya gangguan fisik dapat disebabkan oleh gangguan psikis dan sebaliknya gangguan-gangguan psikis disebabkan kondisi fisik seseorang. Penderita DM sadar bahwa penyakitnya tidak dapat sembuh dan dapat mengalami komplikasi yang berat. Pemikiran tentang penyakit yang tidak dapat sembuh dan ancaman komplikasi yang berat membuat penderita DM merasa ansietas bahkan hampir putus asa atau depresi.

Seseorang yang telah menderita DM lebih dari satu tahun akan mengalami gangguan fisik dan psikis. Gangguan fisik dan psikis ini akan menyebabkan stres. Stres pada penderita DM termasuk stress berat karena stress akan dialami seumur hidup (Syahfitriani, 2009).

Awalnya penderita DM menyangkal saat mengetahui dirinya dinyatakan positif terkena diabetes, penderita DM tidak mau menerima kenyataan bahwa harus menjalani hidup sebagai penderita DM. Penderita DM merasa frustasi saat memikirkan komplikasi yang akan penderita DM alami. Penderita DM memandang komplikasi sangat mengerikan dan akan mengganggu kebebasannya sehingga membuat penderita DM stress (Semiardji, 2005).

Apabila seorang pasien secara intens memikirkan komplikasi DM yang sangat mengerikan tentu akan membuat stres dan cemas. Bagi penderita DM, stres sangat menghambat perjalanan hidupnya. Seseorang yang sedang stres, pola makannya tidak teratur. Orang yang sedang stress merasa bahwa cara menghilangkan stres adalah dengan banyak makan dan berdiam diri tanpa melakukan latihan fisik. Pola makan dan latihan fisik yang tidak teratur tentu menjadi malapetaka karena membuat kadar gula menjadi naik. Perubahan fisiologis ini berkaitan erat dengan adanya gangguan pada sistem saraf otonom vegetatif dan sistem endokrin (Sudoyo dkk, 2006).

Relaksasi adalah terapi tradisional yang paling umum dalam keperawatan karena merupakan 
implementasi yang mudah, aman, non invasif dan murah. Relaksasi adalah salah satu perawatan yang paling efisien dalam mengatasi kecemasan. Relaksasi dapat menurunkan ketegangan otot dan meningkatkan hormon yang efektif (preparat $\beta$ adrenergik) dalam meningkatkan penyerapan insulin dan meningkatkan sirkulasi yang mengarah kepada penurunan kadar glukosa darah (Kashaninia, 2011).

Salah satu jenis relaksasi adalah Progressive Muscle Relaxation (PMR). PMR adalah teknik yang populer dalam mengatasi kecemasan, PMR terdiri dari serangkaian latihan yang melibatkan kelompok otot dalam kondisi tegang dan santai. Pelatihan ini memungkinkan subjek untuk bersantai dengan sendirinya saat proses relaksasi otot-otot (Khanna dkk, 2007).

Relaksasi otot progresif (PMR) adalah teknik manajemen stres dan kecemasan teknik. Apabila seorang pasien mengalami stres, gangguan panik, agorafobia atau gangguan kecemasan, teknik ini dapat membantu pasien untuk dapat menenangkan tubuh dan menenangkan pikiran pasien. Melalui latihan secara teratur maka terapi relaksasi otot progresif akan semakin mudah untuk dilakukan dan juga pasien akan dengan cepat mencapai kedalaman dari relaksasi otot progresif.

PMR difokuskan pada gerakan menegang dan melepaskan ketegangan dengan melibatkan 16 kelompok otot yang berbeda. Jacobson berpendapat bahwa ketegangan otot biasanya timbul sebagai produk kecemasan, seseorang dapat mengurangi kecemasan dengan memahami dan belajar bagaimana diri mereka merasakan ketegangan otot yang berubah ke perasaan rileks (Georgiev dkk, 2006).

Adapun Mashudi (2011) menjelaskan gerakan PMR mempunyai fungsi masing-masing, yaitu: gerakan pertama bertujuan untuk melatih otot tangan, gerakan kedua bertujuan untuk melatih otot tangan bagian belakang, gerakan ketiga dimaksudkan untuk melatih otot otot biceps, gerakan keempat ditujukkan untuk melatih otot - otot 
bahu, gerakan kelima adalah gerakan melatih otot-otot di dahi, gerakan keenam bertujuan untuk mengendurkan otot - otot mata, gerakan ketujuh bertujuan untuk mengendurkan ketegangan yang dialami otot - otot rahang, gerakan kedelapan dilakukan dengan tujuan mengendurkan otot - otot sekitar mulut, gerakan kesembilan ditujukkan untuk merilekskan otot - otot leher bagian belakang, gerakan kesepuluh bertujuan untuk melatih otot leher bagian depan, gerakan kesebelas bertujuan untuk melatih otot - otot punggung, gerakan ini dilakukan untuk melemaskan otot - otot dada, gerakan ini bertujuan untuk melatih otot - otot perut, gerakan keempat belas bertujuan untuk melatih otot otot paha, gerakan kelima belas bertujuan untuk melatih otot - otot betis.

Setiap gerakan dilakukan sebanyak dua kali. Gerakan pertama adalah menegangkan otot, kemudian menahan penegangan dengan durasi 8 detik, lalu dilanjutkan dengan gerakan kedua yaitu merelaksasikan secara perlahan - lahan dan selanjutnya merasakan perbedaan antar ketegangan otot dan keadaan rileks.

Relaksasi merupakan cara untuk menurunkan kadar GDP. Relaksasi dapat mengatasi stres dan dapat menurunkan ketegangan otot dan meningkatkan hormon yang efektif (preparat $\beta$ adrenergik) dalam meningkatkan penyerapan insulin dan meningkatkan sirkulasi yang mengarah kepada penurunan kadar glukosa darah (Kashaninia, 2011).

\section{KESIMPULAN}

Artikel ini menjelaskan bahwa PMR sangat efektif dalam menurunkan kadar gula darah penderita DM tipe 2. Hasil penelitian dianggap tidak bias karena responden dipuasakan terlebih dahulu, sehingga data yang didapat adalah kadar gula darah puasa, hal ini membuktikan bahwa PMR akurat sebagai upaya mencegah komplikasi dengan cara menstabilkan kadar GDP. PMR sebaiknya dilakukan dengan durasi minimal 30 menit setiap sesi, dan dilakukan sebanyak dua sesi, pada pagi dan sore hari. Untuk perbaikan, sebaiknya peneliti selanjutnya memperhatikan jumlah sampel, sampel harus lebih besar dan 
pengukuran gula darah sebaiknya dilakukan dengan metode times series. Penelitian selanjutnya juga sebaiknya meneliti efektifitas PMR pada anak-anak, karena pada hasil penelitian ini, sampel yang digunakan adalah lansia.

\section{DAFTAR PUSTAKA}

Casman, Fauziyah, Y., Fitriyana I., \& Triwibowo, C. (2015). perbedaan efektifitas antara latihan fisik dan progressive muscle relaxation (pmr) terhadap penurunan kadar gula darah puasa pada penderita diabetes melitus tipe 2. Jurnal ilmiah PANNMED, 10(2), 246249.

Departemen Kesehatan Republik Indonesia. (2008). Petunjuk Teknis Pengukuran Faktor Resiko Diabetes Melitus. http//:www.depkes.go.id.Diakse $\mathrm{s}$ pada tanggal 12 Desember 2012.

Fathoni, A., Irmawati A., dan Lilik H. (2007). Perbedaan Latihan Fisik Jangka Pendek Dan Jangka PanjangTerhadap Glukosa Darah Pada Penderita Diabetes Mellitus.Jurnal Diabetes Melitus, 3:08(140 - 152).

Georgiev, A., Michel P., Mare D. H., Valentine G., Anastasiya T., dan Davy V. (2012). Acute Effects of Progressive Muscle Relaxation on State Anxiety and Subjective Well - Being in Chronic Bulgarian Patient with Schizophrenia. Psychiatria
Danubina Journal, 24:4 (367372).

Kashaninia, Z. (2011). The Effect of Swedish Massage on Glycohemoglobin in Children with Diabetes Mellitus. Iranian Rehabilitation Journal, 9:12(16 -20).

Khanna, A., Maman P., dan Jaspal S. S. (2007). Efficacy of Relaxation Techniques in Pulse Rate Among Highly Stressed Femals. Calicut Medical Journal, 5:5(1-3).

Mashudi. (2011). Pengaruh progressive muscle relaxation terhadap kadar glukosa darah pasien diabetes melitus tipe 2 di rumah sakit umum daerah raden mattaher jambi. Universitas Indonesia Depok: Tesis yang tidak dipublikasikan.

Mashudi. (2012). Pengaruh progressive muscle relaxation terhadap kadar glukosa darah pada pasien diabetes melitus tipe 2 di Rumah Sakit Umum Daerah Raden Mattaher Jambi. Jurnal Health \& Sport, 5(3), 686-694.

Sachdev, Y. (2009). Clinical Endocrinology and Diabetes Mellitus. New Delhi. Jaypee Brothers Medical Publisher.

Soewondo, P. (2005). Pemantauan Pengendalian Diabetes Melitus dalamPenatalaksanaan

DiabetesMelitus Terpadu.

Editor : Soegondo, S., Pradana S., dan Subekti I. Jakarta. FKUI.

Subekti, I. (2005). Apa itu Diabetes : Patofisiologi, Geja dan Tanda dalamPenatalaksanaan 
DiabetesMelitus Terpadu. Editor : Soegondo, S., Pradana S., dan Subekti I. Jakarta. FKUI.

Semiardji, G. (2005). Stres Emosional pada Penyandang Diabetes dalam Penatalaksanaan Diabetes Melitus Terpadu. Editor : Soegondo, S., Pradana S., dan Subekti I. Jakarta. FKUI.

Sudoyo, W.A., Setiyohadi B., Alwi I., Simadibrata M. dan Setiati S. (2006). Buku Ajar Ilmu Penyakit Dalam Jilid II Edisi IV. Jakarta. FKUI.
Sustrani, L. (2006). Diabetes. Jakarta: PT Gramedia Pustaka Utama.

Syahfitriani, E. (2009). Pelatihan Emotional Freedom Technique (EFT) Untuk Menurunkan Tingkat Stress Pada Penderita Diabetes Melitus Tipe 2. Universitas Gadjah Mada Jogjakarta : Tesis yang tidak dipublikasikan. 